\title{
ASSESSMENT AND MODELLING OF DUST CONCENTRATION IN AN OPENCAST COAL MINE IN INDIA
}

\author{
TRIPATHY D.P. ${ }^{1, *}$ \\ DASH T.R. ${ }^{1}$ \\ BADU A. ${ }^{1}$ \\ KANUNGO R. ${ }^{2}$
}

\author{
Department of Mining Engineering, National Institute of Technology \\ Rourkela, Odisha, India -769008 \\ Sun Consultancy and Services, Engineers Colony \\ Budheshwari, Bhubaneswar - 751006
}

Received: $28 / 02 / 2015$

Accepted: $15 / 11 / 2015$

Available online: $25 / 11 / 2015$

*to whom all correspondence should be addressed: e-mail: trdash86@gmail.com

\section{ABSTRACT}

Dust pollution is a major problem in opencast mines. Many activities are associated with generation of dust that makes a cloud of pollutant at the work environment and the surrounding areas. Activities as drilling, blasting, transportation, surface miner etc. are the principal sources of generation of dust in mines. This paper focuses on the monitoring of dust level at different operational areas of the mine, characterization of dust collected from different sources, personal exposure of dust and finally prediction of dust concentration at different locations of the mine and nearby areas using AERMOD software. The study was conducted at Lakhanpur opencast mine of MCL (Mahanadi Coalfields Limited), a subsidiary body of CIL (Coal India Limited) the largest coal producing company of the world. The study was done in the month of December 2013, using DustTrakll at nine different locations in the mine. The quartz content of dust was determined using FTIR analysis. Personal Dust Sampler (PDS) was used to determine the personal dust exposure value for different workers. Dust dispersion modelling was done by using AERMOD and isopleths were plotted.

Keywords: Dust, DustTrakII, Quartz, FTIR, AERMOD

\section{Introduction}

Dust generation and its dispersion has been the major concern in open cast mines. Major mining activities in deep open pit coal mines range from exploration to the processing of end product that primarily contribute particulate matter (PM), dominantly $\mathrm{PM}_{10}$ leading to the problem of air pollution and related health hazards. Hence, the monitoring and analysis of ambient air quality is very important in large opencast coal mines. Monitoring only gives the idea of presence of pollutant whereas the analysis will give the composition of that pollutants. Air dispersion models are designed to predict the fate and transport of emissions of pollutants into the atmosphere. Pollutants once emitted will mix in the ambient air, where physical processes, such as turbulence and chemical reactions, cause the primary pollutants to disperse and their concentration to decrease. Air dispersion models predict the ambient air concentrations of a compound at specific spatial locations (called receptors) using mathematical equations that represent the numerous and complex meteorological processes responsible for dispersion. Inputs to a dust dispersion model typically include meteorological data, source emission data in the form of a mass emission rate, dimensions of nearby structures and local terrain information. Dust dispersion modelling is used to predict the fate and transport of dust emissions from industrial sources to comply with regulatory requirements, environmental and health standards, and facility design criteria. Modelling 
dust concentrations at receptors in a community is a crucial first step in assessing any potential risk to human health or the environment.

Opencast coal mining involves various operations e.g. overburden removal, drilling, blasting, mineral loading, haulage and unloading that generate particulates due to various mechanisms. It has been observed that out of total particulates generated, the $\mathrm{PM}_{10}$ constitute one-third to half (Ghose \& Majee, 2007; Trivedi et al., 2009). Overburden removal contributes $7 \%$ of total particulate matter whereas $1 \%$ from top soil removal, $72 \%$ from coal processing, $3 \%$ from coal extraction and $17 \%$ from wind erosion.

Mishra and Jha, (2010) have carried out dispersion modelling in an opencast coal mine and validated the results with the actual field data. They have assessed activity wise dust generation potential and studied distance versus dust concentration to determine impact zone of dust concentration. Numerous epidemiological studies have shown that the association between particulate air pollution and varying serious health effects like the aggravation of existing respiratory and cardiovascular diseases or even lung cancer incidence (Dominici et al., 2005). Trivedi et al., (2008) examined different sources of dust generation and quantified dust emissions from different point, area and line sources in an opencast coal mine. They made air quality modelling using Fugitive Dust Model. Chaulya et al., (2002) carried out study for determination of emission rate for SPM to calculate emission rate for various opencast mining activities. Two commonly used air quality models were used for the validation purpose. Ghosh and Majee, (2007) conducted an investigation to determine air borne dust created by opencast mines at Jharia coal field. Kumari et al., (2011) carried out a study to determine quartz content in airborne respirable dust (ARD) using FTIR spectrometer. Mukherjee et al., (2005) assessed respirable dust, free silica content and personal exposure of the miners to find the risk of coal worker's pneumoconiosis in nine coal mines of eastern India. Silverman et al., (2007) used air quality models to predict the fate and transport of air emissions from industrial sources to comply with federal and state regulatory requirements and environmental standards, as well as to determine pollution control requirements.

In the study the dust concentration level was measured by DustTrakll for different operational activity, then samples from about nine locations were collected and analysed for the determination of quartz content. By considering the hazardous nature of the quartz to the miners personal dust sampling was done for specific workers to determine the personal exposure with reference to the prescribed standard.

\section{Materials and Methods}

\subsection{Study area}

Lakhanpur OCP is situated in Lakhanpur Tahsil of Jharsuguda district in Orissa. It is located about $11 \mathrm{~km}$ south of the nearest Belpahar Railway Station of South Eastern Railway on Howrah- Mumbai Main Line. A Highway NH 200 connecting Jharsuguda-Raigarh (Chattisgarh) passes at a distance of $2 \mathrm{kms}$ on the western side of the mine. It is surrounded by Lilari nallah \& Lilari OCP in north, Belpahar OCM in the east, Khusuraloi Reserve forest in the south and Khairkuni, Tingismal, Lakhanpur villages in the west. It is approachable by an all-weather road. It lies between latitudes $21^{\prime} 43^{\prime} 30^{\prime \prime}$ to $21^{\prime} 46^{\prime} 44^{\prime \prime}$ and longitudes 83'49'11' to 83'52'38'. The mine was opened in 1991 and started its production since 1993.

The area is fully loaded by different mining and industrial activities, which makes the quality of air more sensitive. In this area as mining operation is the main activity, dust pollution is the dominating factor for air pollution. There are different sources identified in that area for generation of dust like haul road, surface miner, drilling, loading- unloading, and transportation etc. Blasting is not taken into consideration during the dust measurement by DustTrakll, as it is an instantaneous source. Most of the dust generation sources in mine are fugitive in nature.

The mine was divided into 3 quarries, i.e. quarry 1 , quarry 2 and quarry 3 . At present, quarry 1 is being worked by conventional shovel- dumper combination for overburden (OB) and by surface miner and tippers combination for coal. The total mines area was about $4.84 \mathrm{~km} 2$. The detail map of the study area is shown in Figure 1. 


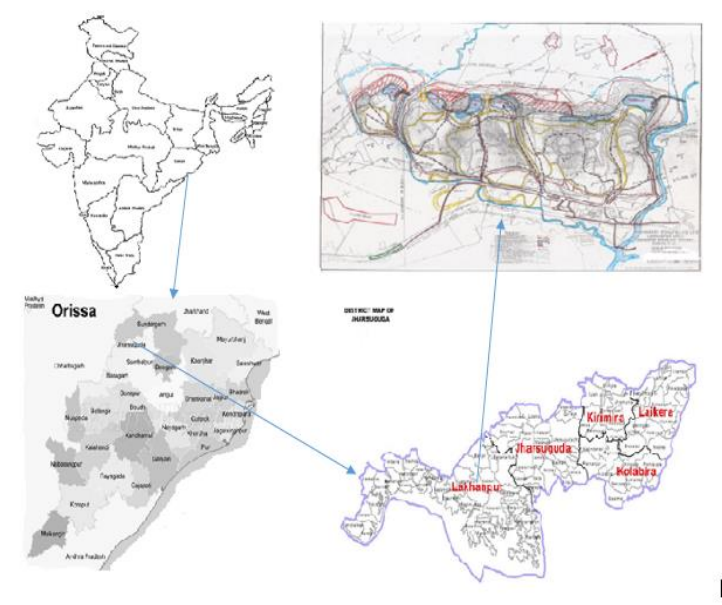

Figure 1. Map of the Study Area

\subsection{Dust Measurement}

The dust concentration was monitored by using an instrument DustTrakll. It is a real time dust monitoring instrument, working by the principle of optical detection of scattered lights. These instruments are used for spot check of dust concentration in workplace. The intensity of the scattered light is given by:

$$
\frac{\mathrm{Is}}{\mathrm{lo}}=\mathrm{KND}^{2}
$$

Where,

Is = Intensity of scattered light,

lo = Intensity of incident light,

$\mathrm{N}=$ No. of particles per unit volume,

$\mathrm{D}=$ Diameter of particles,

$\mathrm{K}=$ constant depending upon the refractive index, absorption co-efficient and shape of the particles as well as the wavelength of the light, angle of scattering and the distance of the point of observation from dust cloud.

The instrument has four different size selectors as $1 \mu \mathrm{m}, 2.5 \mu \mathrm{m}, 4 \mu \mathrm{m}, 10 \mu \mathrm{m}$ and an impactor plate. The dust can be measured by using different size selectors, which restrict the entry of the particles of that selected size and the concentration can be measured. The picture of the instrument with size selective impactors is shown in Figure 2.

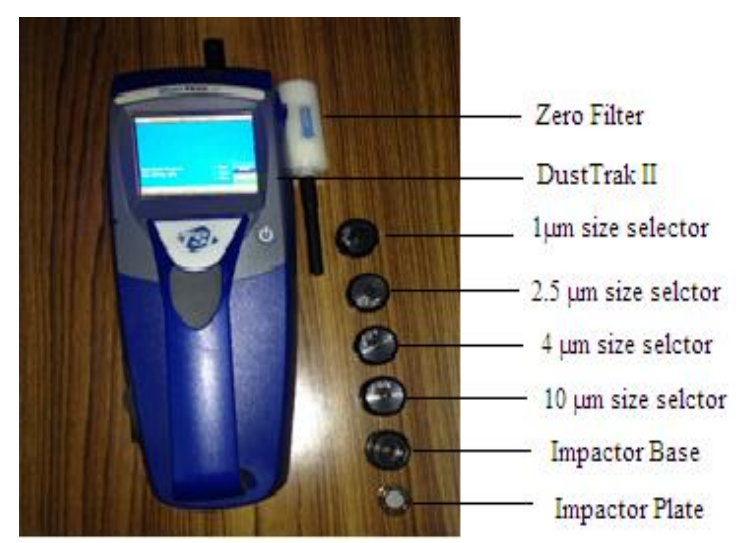

Figure 2. DustTraklI 
As per The Coal Mines Regulation, 1957 section: 123, the instrument was kept within $1 \mathrm{~m}$ of the dust source. The measurement of dust during blasting was done by keeping the instrument in a safe zone. Different size selectors like PM10, PM4, PM2.5 and PM1 were used in a sequence for a period of 1 hour to determine dust concentration at selected sampling locations with different operational activities.

\subsection{Determination of quartz content of dust}

Quartz is a major constituent of coal mining dust. The quartz content of dust is very important because of its hazardous nature to different miners and workers working there. The WHO /ILO International programme (1995) on the global elimination of silicosis puts emphasis on characterization of dust and its sources. Fourier Transform Infra-Red technique (FTIR) was used for the determination of quartz content of mine dust. Dust samples were collected from nine different locations of the mine to measure quartz content of dust through FTIR. The dust samples were sieved with 200 mesh size and then heated at $105^{\circ} \mathrm{C}$ for one and half hour for removal of moisture. Then a known weight of dust is mixed with $200 \mathrm{mg}$ of $\mathrm{KBr}$. The mixture was finely mixed with a pestle and a pellet is made using pellet maker. FTIR of the pellet was carried out at from $400 \mathrm{~cm}^{-1}$ to $4000 \mathrm{~cm}^{-1}$ at a resolution of $4 \mathrm{~cm}^{-1}$. The absorbance peaks at $800 \mathrm{~cm}^{-1}$ was compared with standard quartz to determine quartz content of the sample. The whole experiment was carried out as per the guidelines of NIOSH-7602 (Silica, Crystalline by IR).

\subsection{Personal Dust Exposure Sampling}

Personal dust exposure of four different workers associated with mining operations was measured using Personal Dust Sampler (PDS-Model No- APM-800). Those four persons were selected for the survey basing

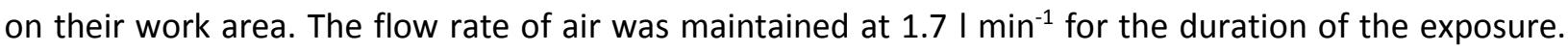
Cyclone was used to measure dust within the respirable zone i.e. within $5 \mu \mathrm{m}$.

\subsection{Dust Dispersion Modelling}

Dispersion modelling is a modern tool for prediction of pollution concentration at different locations within or surrounding the mining area. This modelling process uses a software prepared by lakes environmental in accordance with guidelines prescribed by USEPA (United State Environmental Protection Agency). In this study AERMOD software was used for prediction of dust dispersion. It is a regulatory steady-state plume modeling. The AERMOD model includes a wide range of options for modeling air quality impacts of pollution sources. The model is capable of handling multiple sources, including point, volume, and area source types. The AERMOD was developed from the Industrial Sources Complex Short Term Model (ISCST3) by incorporating more complex algorithms and concepts, i.e., planetary boundary layer (PBL) theory and advanced methods for complex terrains. As with ISCST3, the AERMOD is considered accurate for dispersion modeling at distances not exceeding $50 \mathrm{~km}$ from the emission source (US EPA, 2005). The model is composed of three parts: AERMOD Meteorological preprocessor (AERMET), AERMOD Terrain Preprocessor (AERMAP) and AERMOD Gaussian Plume Model with the PBL modules. For the modelling using AERMOD meteorological data are quite important, so meteorological data for the full year were collected from nearby weather station of the study area. The flow sheet for the process of modelling through AERMOD is shown in Figure 3.

Goole earth can be used as an additional feature of AERMOD. Site domain boundary, sources of emission, uniform Cartesian receptor grids, contours, terrain contours generated by AERMOD can be exported to google earth to have a natural view of the dispersion and isopleths. It provides a user friendly interface to see the output generated by AERMOD. It is also useful to see the extent of dispersion of the pollutants around the source with satellite view.

The emission rate for mining operation was calculated by an empirical formula given below:

Emission of SPM for Overall mine:

$$
E=\left[u^{0.4} a^{0.2}\left\{9.7+0.01 p+\frac{b}{4+0.3 b}\right] \quad\right. \text { (Chaulya et al., 2002) }
$$


Where,

$\mathrm{u}$ :wind speed $\left(\mathrm{m} \mathrm{s}^{-1}\right)$,

$\mathrm{p}:$ coal/mineral production (MT/Annum),

$\mathrm{b}: \mathrm{OB}$ handling ( $\mathrm{Mm}^{3} /$ Annum);

$\mathrm{E}$ : emission rate $\left(\mathrm{g} \mathrm{s}^{-1}\right)$.

The different parameter for Lakhanpur Opencast Project were collected from present operation status of the mine. The wind speed (u) was $2.33 \mathrm{~m} \mathrm{sec}^{-1}$, Area (a) was $4.84 \mathrm{~km}^{2}$, Coal Production (p) was 15 MT/Annum and Overburden handling (b) was $14.91 \mathrm{Mm}^{3} /$ Annum.

By using all the values, the emission was calculated as, E =22.2836093895 $\mathrm{g} \mathrm{s}^{-1}$, which was used in the AERMOD view software for the modelling purpose.

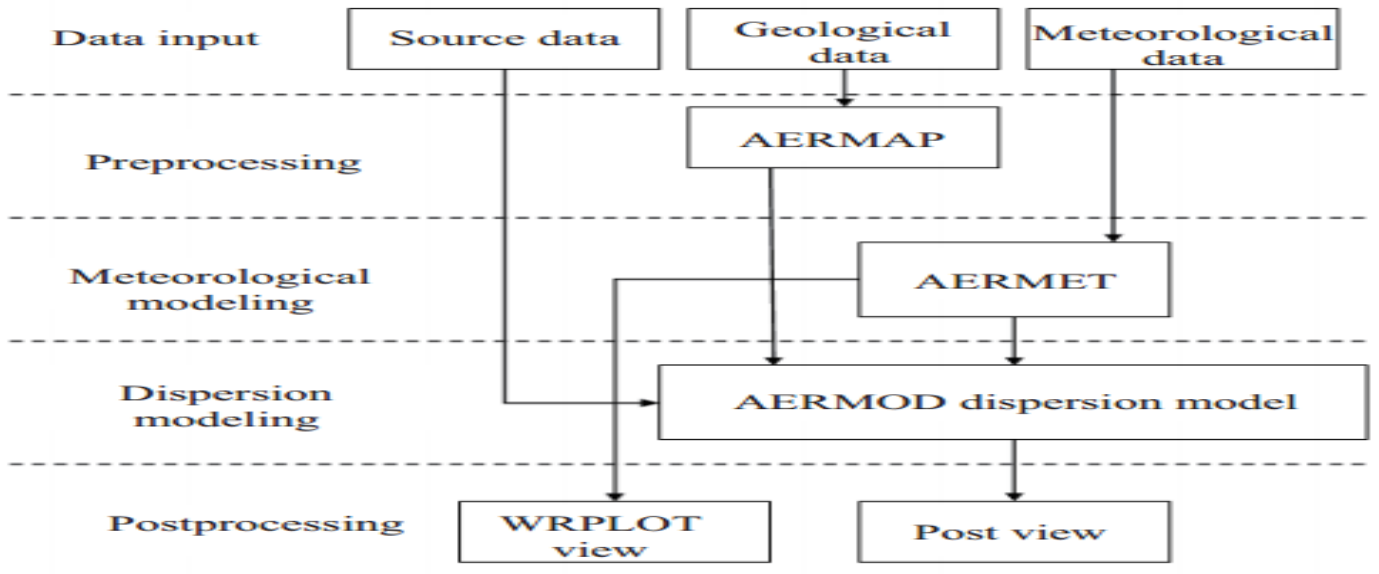

Figure 3. Process Flowchart of AERMOD Modelling

\section{Results and discussion}

\subsection{Dust Monitoring in the Operation areas}

Monitoring was done by DustTrak II at nearly nine locations. The comparison of average and maximum dust concentration in PM10, PM4, PM2.5 and PM1 at different locations was plotted in Figure 4. The result showed that drilling was the most polluting source in PM2.5, PM4 and PM10 whereas surface miner was the most polluting source in PM1.0.
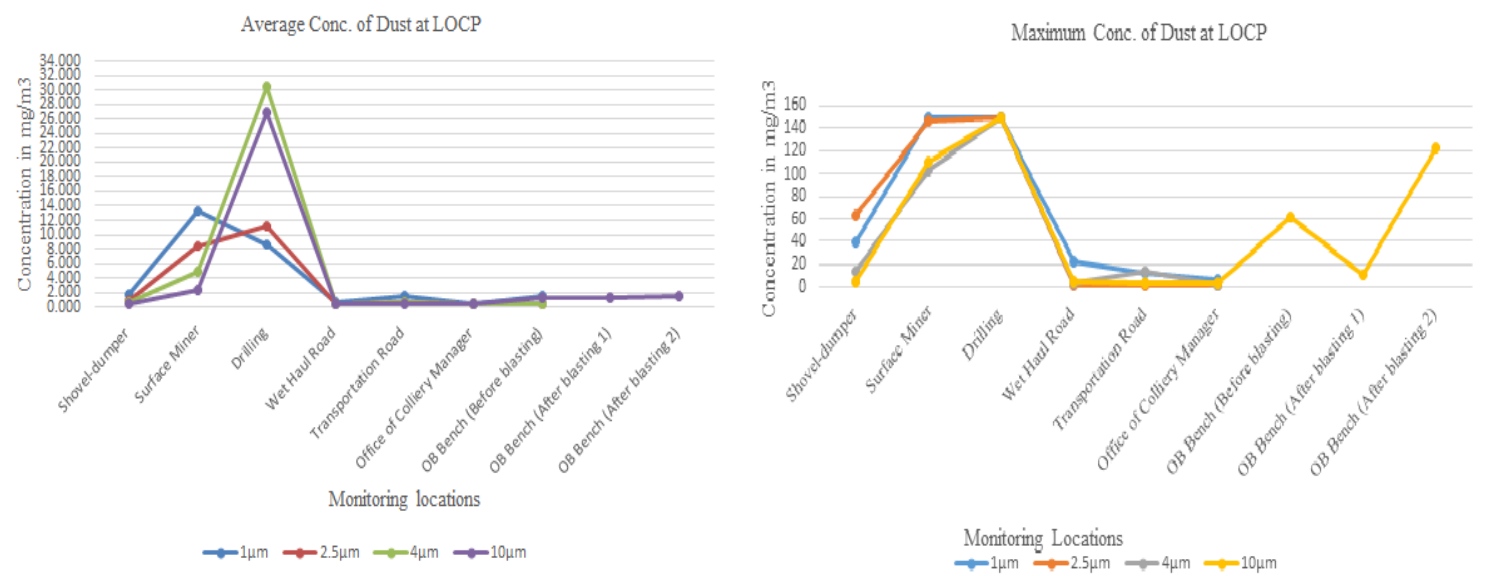

Figure 4. Average and Maximum Dust Concentration at LOCP 
The data showed that at drilling point maximum concentration was obtained for $\mathrm{PM}_{1.0}, \mathrm{PM}_{2.5}, \mathrm{PM}_{4.0}$ \& $\mathrm{PM}_{10}$. During drilling process a lot of dust generated and which is hazardous to the driller. Insufficient use of water for drilling and cutting purpose at these locations resulted in generation of high quantity of fine dusts. Surface miner was the second most polluting source at all size range.

As blasting is an instantaneous operation so to collect values for all size of particles with the instrument is not possible. For that reason only monitoring was done for $10 \mu \mathrm{m}$ only. Frequent blasting i.e., one after another increased the dust level up to a maximum mark. The overall result shows that surface miner, drilling and blasting were the dominating dust producer in the study area.

\subsection{Personal Dust Exposure Measurement of Different Workers}

MSHA is planning to prescribe from Aug. 1, 2016, that concentration limits for respirable coal mine dust will be lowered from 2.0 milligrams of dust per cubic meter of air $\left(\mathrm{mg} \mathrm{m}^{-3}\right)$ to $1.5 \mathrm{mg} \mathrm{m}^{-3}$ at underground and surface coal mines. Starting Feb. 1, 2016, mine operators must use continuous personal dust monitors to monitor the exposures of underground coal miners in occupations exposed to the highest respirable dust concentrations and the exposures of miners who have evidence of the development of pneumoconiosis (MSHA, 2014). In October 2010, the Department of Labor's (DOL) Mine Safety and Health Administration (MSHA) the federal agency responsible for setting and enforcing mine safety and health standards proposed lowering the existing concentration limit for respirable coal mine dust from 2.0 to milligrams of dust per cubic meter of air $\left(\mathrm{mg} \mathrm{m}^{-3}\right)$ to $1.0 \mathrm{mg} \mathrm{m}^{-3}$. The personal dust sampling was done for four different workers of different activities and the result was plotted in Figure 5.

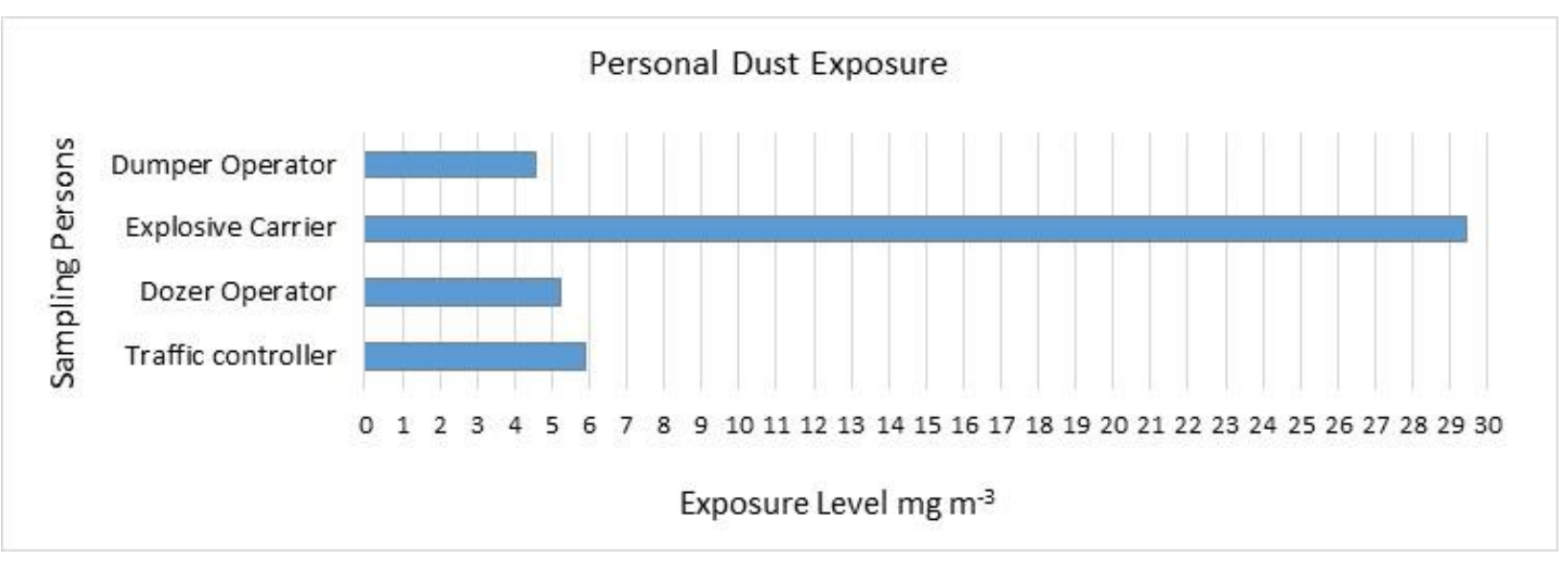

Figure 5. Personal Dust Exposure of Workers

Personal dust exposure to different workers was plotted in Figure 5. The personal dust monitoring results show that at all locations of sampling, the dust exposure level were higher than $2 \mathrm{mg} \mathrm{m}^{-3}$. The transportation road was conditioned by water sprinkling arrangement so the dust level could be comparatively lowered. It is desired to provide with personal protective devices like dust mask to workers or minimize dust concentration at source by dust suppression measures.

\subsection{Quartz analysis}

Samples collected from various sources were analyzed and the results shown in the Table 1. Maximum quartz content was obtained at wet haul road-1 whereas minimum quartz content was found at coal transport road-3.

The analysis data shows that at all sampling location the quartz content in the dust are far below the permissible limit. According to the guidelines given by Mine Safety and Health Administration (MSHA) and centre for diseases control and prevention (CDC) the quartz content of the dust should be $<5 \%$ for 8 hour exposure. If the quartz content exceed then the exposure limit it should be lowered down (Sharon, M. A., 2002; Gerald J. Joy., 2011). 
Table 1. Quartz Analysis Result

\begin{tabular}{|c|c|c|c|c|c|c|c|c|c|c|}
\hline $\begin{array}{c}\text { Sampling } \\
\text { Location }\end{array}$ & $\begin{array}{c}\text { Mine } \\
\text { Road }\end{array}$ & $\begin{array}{c}\text { Wet } \\
\text { Haul } \\
\text { Road-1 }\end{array}$ & $\begin{array}{c}\text { Wet } \\
\text { Haul } \\
\text { Road-2 }\end{array}$ & $\begin{array}{c}\text { Wet } \\
\text { Haul } \\
\text { Road-3 }\end{array}$ & $\begin{array}{c}\text { Wet } \\
\text { Haul } \\
\text { Road-4 }\end{array}$ & $\begin{array}{c}\text { O/B } \\
\text { Bench } \\
\text { Road }\end{array}$ & $\begin{array}{c}\text { Coal } \\
\text { Transp } \\
\text { ort } \\
\text { Road-1 }\end{array}$ & $\begin{array}{c}\text { Coal } \\
\text { Transp } \\
\text { ort } \\
\text { Road-2 }\end{array}$ & $\begin{array}{c}\text { Coal } \\
\text { Transp } \\
\text { ort } \\
\text { Road-3 } \\
\text { MCL }\end{array}$ & Drilling \\
\hline $\begin{array}{c}\text { Quartz } \\
\text { Content } \\
(\%)\end{array}$ & 0.442 & 0.490 & 0.338 & 0.370 & 0.360 & 0.341 & 0.363 & 0.273 & 0.229 & 0.293 \\
\hline
\end{tabular}

\subsection{Meteorological analysis of the area}

Meteorological data was collected from the nearby weather station. These parameters are essential for input in the AERMET module of AERMOD. From the input two type of files were generated, one is the wind rose diagram for the year and other was AERMET file which was used as an input file in the AERMOD. Cloud Cover (tenths), Dry Bulb Temp $\left({ }^{\circ} \mathrm{C}\right)$, Relative Humidity (\%), Station Pressure (mbar), Wind Direction (deg), Wind Speed $\left(\mathrm{m} \mathrm{s}^{-1}\right)$, Ceiling Height $(\mathrm{m})$, Hourly Precipitation (1/100th of inch), Global Horizontal Radiation $\left(\mathrm{Wh} \mathrm{m}^{-3}\right)$ were taken as meteorological parameter for the study. The direction suggests the direction from which the wind blows. Figure 6 shows the Wind rose diagram for the data with 36 directions. Wind frequency classification was also plotted. It shows percentage of wind with a different speed ranges. It also shows the time for which calm situation prevailed. The calm state prevailed for $34.17 \%$. The average wind speed for the whole year was found to be $2.33 \mathrm{~m} \mathrm{~s}^{-1}$. The predominant wind direction was North-Easterly to South-Westerly.
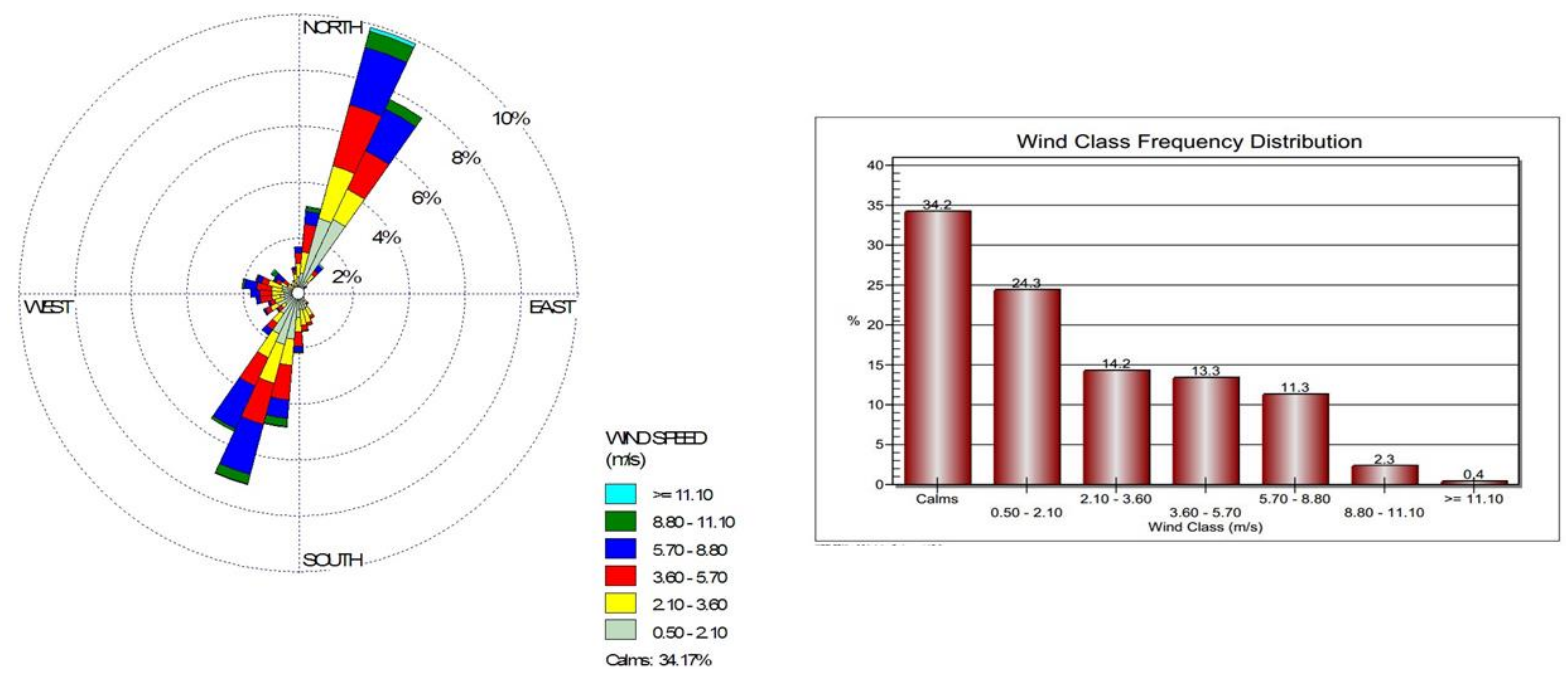

Figure 6. Wind Rose Diagram in 36 Direction and Wind Class Frequency Distribution

\subsection{Modelling by using AERMOD software}

The predicted concentration at different locations in and around the mine was obtained from AERMOD. The predicted dust concentrations values for highest 24 hour and annual average at different locations are plotted in Figure 7. At most of all the locations the model predicted that the highest 24 hour values of concentration of $\mathrm{PM}_{10}$ level was higher than NAAQS limit of $100 \mu \mathrm{g} \mathrm{m}^{-3}$. Similarly another comparison was made for the annual average predicted dust concentration in $\mathrm{PM}_{10}$. It can be seen that debarring a few locations, dust concentration was below the NAAQS limit of $100 \mu \mathrm{g} \mathrm{m}^{-3}$. 

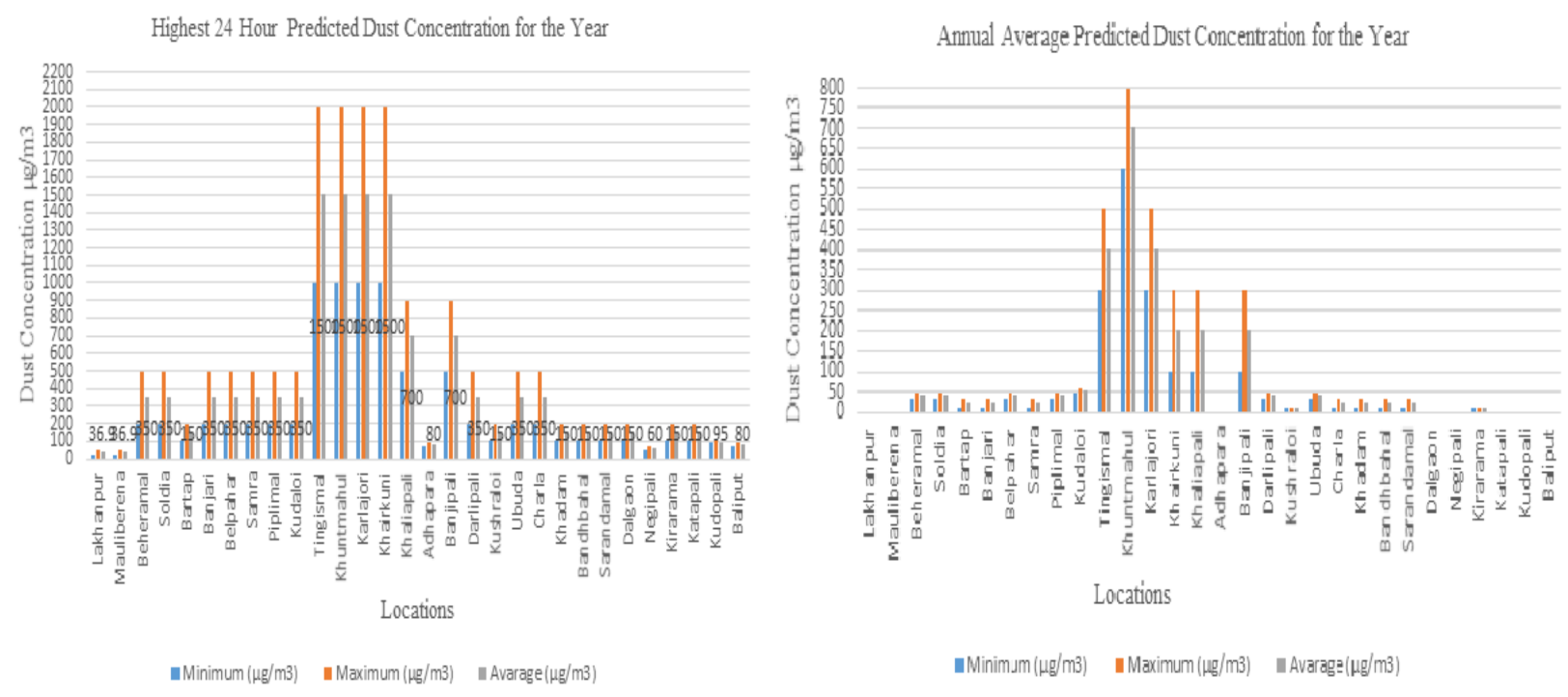

Figure 7. Predicted Dust Concentration at Different Locations

Figure 8 is the model obtained from AERMOD as final output for highest 24 hour predicted dust concentrations and annual average dust concentrations. Color scale was used in the model to specify the level of dust at different locations.

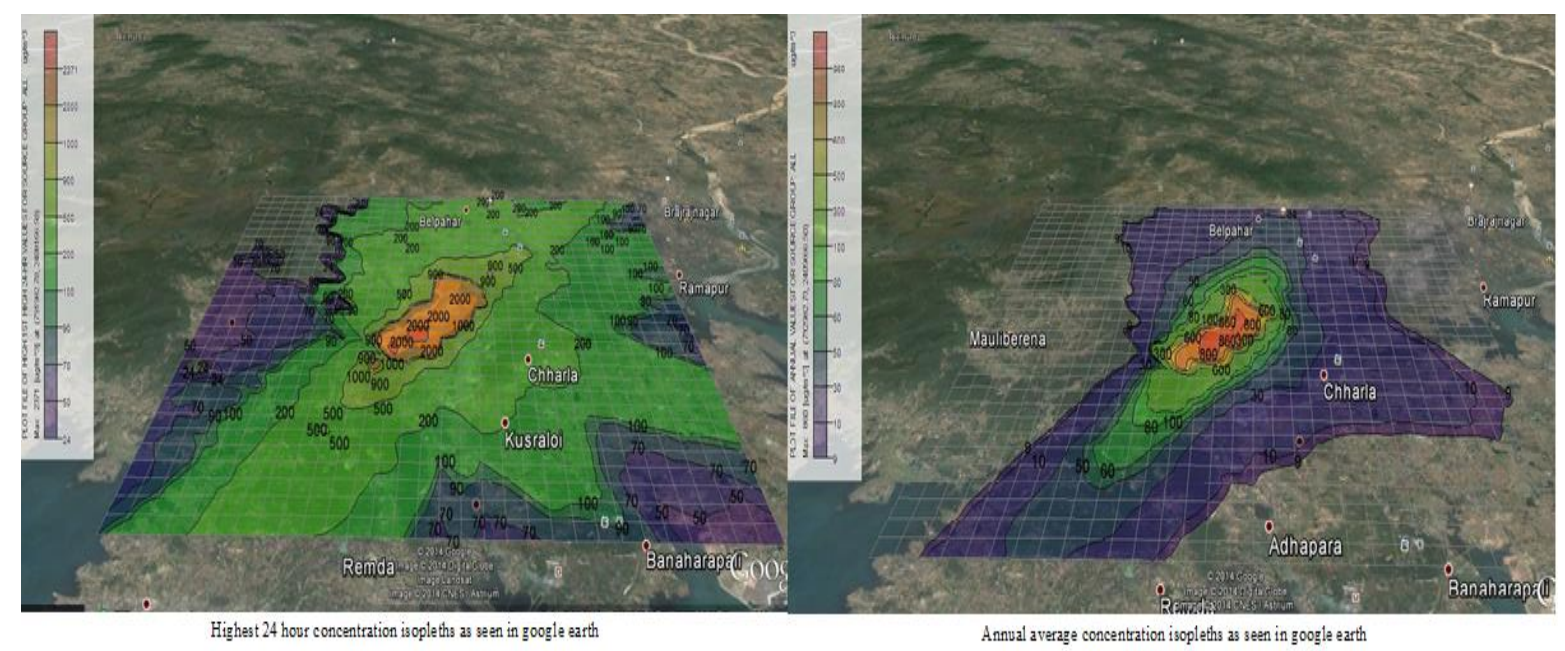

Figure 8. Dust Prediction Model

\section{Conclusion}

The field monitoring of dust concentrations using DustTrak-II at LOCP suggests that, the maximum dust concentration was obtained at drilling point with average concentration of $26.8 \mathrm{mg} \mathrm{m}^{-3}$ and maximum concentration of $150.0 \mathrm{mg} \mathrm{m}^{-3}$ in $\mathrm{PM}_{10}$ range. Minimum mean dust concentration was found at loading point at $0.474 \mathrm{mg} \mathrm{m}^{-3}$ in the $\mathrm{PM}_{10}$ range. Drilling and Surface miner operations were found to be the major sources of dust generation.

The data from personal dust exposure monitoring of workers using PDS (Personal Dust Sampler- APM500) suggest that, the dust exposure of worker was the maximum for explosive carrier at $29.41 \mathrm{mg} \mathrm{m}^{-3}$ which is much above the regulatory limit of $3 \mathrm{mg} \mathrm{m}^{-3}$. In general, for most of the employees under study, personal respirable dust exposure was found to be beyond the permissible limit. 
The characterization of the collected dust samples suggest that the dust from coal transport road was having minimum quartz content i.e., $0.23 \%$, whereas maximum quartz content was found at wet haul road of LOCP i.e., $0.49 \%$.

The dust dispersion modelling explained about the predicted dust concentration and suggest that, for 24 hour period for the year, the highest dust concentration for $\mathrm{PM}_{10}$ at all other places except at Lakhanpur, Mauliberena, Adhapara, Negipali, Kudopali and Baliput were found to be above NAAQS limit of $100 \mu \mathrm{g} \mathrm{m}^{-3}$. The annual average of dust concentration, at most of the places at and around LOCP were found to be below NAAQS limit of $60 \mathrm{\mu g} \mathrm{m}^{-3}$ except at Tingismal, Khuntmahul, Karlajori, Khairkuni, Khaliapali, Banjipali.

\section{References}

AERMOD View Overview. http://www.weblakes.com/products/aermod/index.html. Last accessed 2nd May 2014.

Basis for Proposed Exposure Limit on Respirable Coal Mine Dust and Possible Approaches for Lowering Dust Levels. April 2014. http://gao.gov/assets/670/662410.pdf. Last accessed 2nd May 2014.

Central Pollution Control Board. India, 2011.Guidelines for the Measurement of Ambient Air Pollutants, Volume-I. Available online at http://cpcb.nic.in/NAAQSManualVolumel.pdf.

Chaulya S.K., Chakraborty M.K., Ahmad M., Singh R.S., Bondyopadhay C.G., Mondal C. and Pal D. (2002), Development of Empirical Formulae to Determine Emission Rate from Various Opencast Coalmining Operations, CMRI.

Dominici F., McDermott A., Daniels M., Zeger S.L. and Samet J.M. (2005), Revised analyses of the national morbidity, mortality, and air pollution study: Mortality among residents of 90 cities, Journal of Toxicology and Environmental Health-Part A-Current Issues, 68, 1071-1092.

Gerald J. Joy., 2011. Evaluation of the Approach to Respirable Quartz Exposure Control in U.S. Coal Mines. http://www.cdc.gov/niosh/mining/UserFiles/works/pdfs/eotat.pdf. Last accessed 2nd May 2014.

Ghose M.K. (2007), Generation and Quantification of Hazardous Dusts from Coal Mining in the Indian Context, Environ Monit. Assess, 130, 35-45.

Ghose M.K. and Majee S.R. (2007), Characteristics of Hazardous Airborne Dust around an Indian Surface Coal Mining Area, Environmental Monitoring and Assessment, 130, 17-25.

Kumari S., Kumar R., Mishra K.K., Pandey J.K., Udayabhanu G.N. and Bandopadhyaya A.K. (2011), Determination of quartz and its abundance in respirable airborne dust in both coal and metal mines in India, Procedia Engineering, 26, $1810-1819$.

Mishra P.C. and Jha S. (2010), Dust Dispersion Modeling In Opencast Coal Mines and Control of Dispersion in Mahanadi Coalfields of Orissa. Paper presented in International Conference on Environment, Energy and Development (from Stockholm to Copenhagen and beyond) December 10 - 12, 2010, Sambalpur University. Published in The Bioscan, Vol. 2; 479-500; 2010.

Mine Safety and Health Administration-MSHA, 2014. Final rule issued to better protect coal miners' health. Available online at http://www.msha.gov/endblacklung/\#.U3s8GdKSxvA. Last accessed 2nd May 2014.

Mukherjee A.K., Bhattacharya S.K. and Saiyed H.N. (2005), Assessment of respirable dust and its free silica contents in different Indian coalmines, Industrial Health, 43, 277-284.

Operation manual of DustTrak II. www.tsi.com/.../8530-8531-8532-DustTrak_II-6001893-web.pdf. Last accessed 22nd April 2014.

Sharon M.A. (2002), Infrared Analysis of Respirable Coal Mine Dust for Quartz: Thirty Five Years. http://www.msha.gov/S\&Hinfo/techrpt/dust/astm_IR.pdf. Last accessed 3rd May 2014.

Silverman K.C., Tell G.J., Sargen E.V. and Qui Z. (2007), Comparison of the Industrial Source Complex and AERMOD Dispersion Models: Case Study for Human Health Risk Assessment, Journal of the Air \& Waste Management Association, 57(12), 1439-1446. DOI: 10.3155/1047-3289.57.12.1439.

The Coal Mines Regulations, 1957. Available online at, www.dgms.net/cmr.pdf. Last accessed 30th April 2014.

Trivedi R., Chakraborthy M.K. and Tewary B.K. (2009), Dust deposition using fugitive dust model at an opencast coal project of western coalfields limited, India, Journal of Scientific and Industrial Research, 68, 71-78. 
Trivedi R. and Chakraborty M.K. (2008), Dust generation and its dispersion due to mining activities in Durgapur open cast coal project of W.C.L-A Case Study, The Indian Mining \& Engineering Journal, February, pp. 24 - 3146.

Trivedi R., Chakraborty M.K. and Tewary B.K. (2009), Dust Dispersion Modeling using fugitive dust model at an opencast coal project of Western Coalfields Limited, India, Journal of Scientific \& Industrial Research, 68, 71-78.

U.S. Department of Labor Mine Safety and Health Administration. Determining the Quartz Content of Respirable Dust by FTIR http://www.msha.gov/S\&Hinfo/techrpt/dust/detqtz.pdf. Last accessed 2nd May 2014. 